ISSN: 2224-0616

Int. J. Agril. Res. Innov. Tech. 9(2): 1-8, December 2019

DOI: https://doi.org/10.3329/ijarit.v9i2.45403

Available online at http://ijarit.webs.com https://www.banglajol.info/index.php/IJARIT

\title{
AGRONOMIC POTENTIAL VALUE OF HOUSEHOLD URBAN SOLID WASTES BY COMPOSTING AND COMPOSTS QUALITY ASSESSMENT
}

\author{
K.K.A. Alate ${ }^{1}$, G. Mawussi ${ }^{*}$, K.D. Ayisah ${ }^{2}$ and K. Sanda ${ }^{1}$ \\ Received 28 June 2019, Revised 20 November 2019, Accepted 24 December 2019, Published online 31 December 2019
}

\begin{abstract}
Using composting technology, the biodegradable fraction of solid wastes collected from Agbalepedogan district in Lomé (Togo) was transformed into composts with no phytotoxicity suitable for use in agriculture. The household urban solid wastes were mixed with poultry manure and Mucuna pruriens leaves in appropriate percentages and transformed into composts. The composting process was monitored by temperature, $\mathrm{pH}$ and $\mathrm{C} / \mathrm{N}$ ratio controlling. The composts quality was appreciated by phytotoxicity test, particle size distribution, contents of nitrogen, phosphorus, potassium, organic matter and trace elements. The results showed that composts particle size distribution presented four fractions $(>10 \mathrm{~mm}, 5-10 \mathrm{~mm}, 2-5 \mathrm{~mm}$ and $\leq 2 \mathrm{~mm}$ ) whose average percentages are respectively $9.04 \pm 0.2 \% ; 10.71 \pm 0.2 \% ; 12.68 \pm 0.4 \%$ and $67.53 \pm 0.6 \%$, respectively. Composts produced contained $1.02 \pm 0.1 \%-2.72 \pm 0.2 \%$ of nitrogen, $1.35 \pm 0.3 \%-2.70 \pm 0.4 \%$ of phosphorus, $1.31 \pm 0.2 \%-1.72 \pm 0.3 \%$ of potassium and $23.50 \pm 0.4 \%-37.75 \pm 0.5 \%$ of organic matter. The $\mathrm{pH}$ in final composts were between $8.50 \pm 0.2$ and $9.00 \pm 0.3$ while $\mathrm{C} / \mathrm{N}$ ratio varying from $8.06 \pm 0.2$ to $13.13 \pm 0.2$. The concentrations of some heavy metals in final products were $79.8 \pm 1.7-140.2 \pm 1.6 \mathrm{mg} / \mathrm{kg} . \mathrm{dm}$ of zinc, $27.1 \pm 1.01-76.6 \pm 1.03 \mathrm{mg} / \mathrm{kg} . \mathrm{dm}$ of copper, $2.07 \pm 0.33-9.19 \pm 0.22 \mathrm{mg} / \mathrm{kg} . \mathrm{dm}$ of lead, $4.13 \pm 0.16-11.05 \pm 0.36 \mathrm{mg} / \mathrm{kg} . \mathrm{dm}$ of nickel and $0.79 \pm 0.02-2.15 \pm 0.03 \mathrm{mg} / \mathrm{kg}$.dm of cadmium. These concentrations were lower than the limited value for heavy metals prescribed by French and US EPA regulation for organic and organic-mineral fertilizers.
\end{abstract}

Keywords: Household Solid Waste, Poultry Manure, Mucuna pruriens, Composting, Composts Quality.

${ }^{1}$ Department of Soil Sciences, Research Laboratory on Agroresources and Environmental Health, School of Agronomy, University of Lome, BP 1515 Lome, Togo.

${ }^{2}$ Department of Plant Science and Improvement, School of Agronomy, University of Lome, BP 1515 Lome, Togo.

*Corresponding author’s email: gmawussi@gmail.com (G. Mawussi)

Cite this article as: Alate, K.K.A., Mawussi, G., Ayisah, K.D. and Sanda, K. 2019. Agronomic potential value of household urban solid wastes by composting and composts quality assessment. Int. J. Agril. Res. Innov. Tech. 9(2): 1-8. DOI: 10.3329/ijarit.v9i2.45403.

\section{Introduction}

The production of urban solid waste is increasing in quantity and diversity in African developing countries and generates huge risks on the environment and the health of populations. The generation of household solid waste has been increasing in Lome, capital of Togo in West Africa, mainly driven by growing global population, urbanization and economic growth, coupled with changing activities and consumption behavior (Koledzi, 2011). A household urban waste is defined as a material whose economic value is zero or negative. In order to secure the ecological balance and an adequate living quality for the human society also in the future, it is more than ever before necessary to manage these wastes, utilize them to the extent possible to save primary resources. Waste management is a major challenge for any society. It contributes to sustained economic activity and enhances public welfare. In recent years, the research showed that, many wastes produced in important quantities may be transformed into an organic fertilizer by composting. Land application of compost obtained from municipal waste is one of the most economical and attractive methods of solving two problems in the developing countries: waste disposal and soil infertility. Therefore, composting is more suitable technology for waste management in developing countries. Compost consists of the relatively stable decomposed organic materials resulting from the accelerated biological degradation of organic materials under controlled and aerobic conditions. Many studies (Ouédraogo et al., 2001; Caravaca et al., 2003; Gamal, 2009) have shown that application of mature composts at reasonable rates improves soil physical properties, increases available soil nutrient levels and plant growth. 
The aim of this study is to assess the agronomic potential value of biodegradable fraction of household urban solid waste collected from Agbalepedogan district in Lome (Togo) by composting, as well as to evaluate the quality of the final product composts.

\section{Materials and Methods}

The composting took place at a large-scale composting platform of the Non Governmental Organization: Clean Natural Ecosystem (ENPRO) situated in Lome $\left(6^{\circ} 10^{\prime} \mathrm{N}, 1^{\circ} 11^{\prime} \mathrm{E}\right.$; with altitude comprises between 19 and $60 \mathrm{~m})$. The household urban solid wastes collected from one district of Lome called Agbalepedogan were transferred to clean area and physically segregated into different inorganic and organic components (Fig. 1). They were sorted by the following categories: biodegradable fraction (wood and wood products, pulp, paper and cardboard, food, food waste, textiles, garden, yard and park waste) and no biodegradable fraction (glass, plastic, metal and other inert waste; fine and sand).

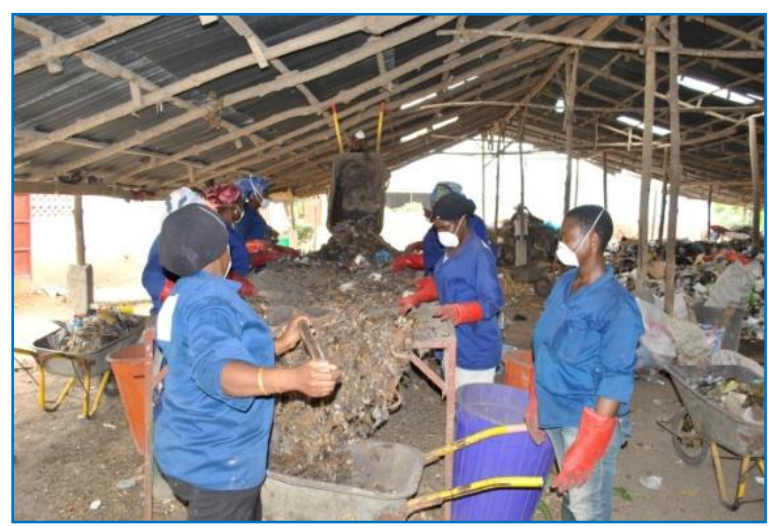

Fig. 1. Physical segregation of household urban solid wastes into different inorganic and organic components.

The urban solid waste biodegradable fraction characterized by high organic carbon and low nitrogen contents, is co-composted with poultry manure and Mucuna pruriens leaves. Four combinations of waste with poultry manure and $M$. pruriens leaves were formulated. In fact, five constructed windrows were carried out in five replicates, one for each combination and a control set with only household urban solid waste as follow:

- Windrow 1: control set composed only household urban solid waste (100\%),

- Windrow 2: mixture of household urban solid waste (85\%) and poultry manure (15\%),

- Windrow 3: mixture of household urban solid waste (70\%) and poultry manure (30\%),

- Windrow 4: mixture of household urban solid waste (85\%) and M. pruriens leaves (15\%),

- Windrow 5: mixture of household urban solid waste (70\%) and $M$. pruriens leaves (30\%).
The windrows produced respectively compost

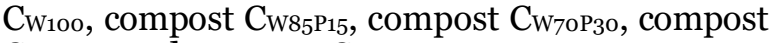

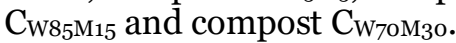

\section{Composting operation}

The windrows had triangular shape with $1.5 \mathrm{~m}$ wide of the base and $1.0-1.5 \mathrm{~m}$ high (Fig. 2). The windrows were turned using a loading shovel twice a week for the first 10 weeks (Fig. 3) and then, the material was allowed to mature for a period of 3 weeks with no turning. A representative sample of approximately $500 \mathrm{~g}$ was taken once a week after turning. The sample was a composite made up from 10 grab subsamples taken along the length on the windrow. The samples were screened through a $10 \mathrm{~mm}$ sieve and kept refrigerated for physicochemical analysis. The moisture was kept at 45 $50 \%$ by adding water. The temperature was monitored daily using mercury thermometers placed near the centre of the pile at six different points along its length and the average of all measurements was recorded. Other parameters controlling are $\mathrm{pH}$ and $\mathrm{C} / \mathrm{N}$ ratio. The composting process involved three phases: pilling (Fig. 2), compost maturation (Fig. 3) and compost screening (Fig. 4).

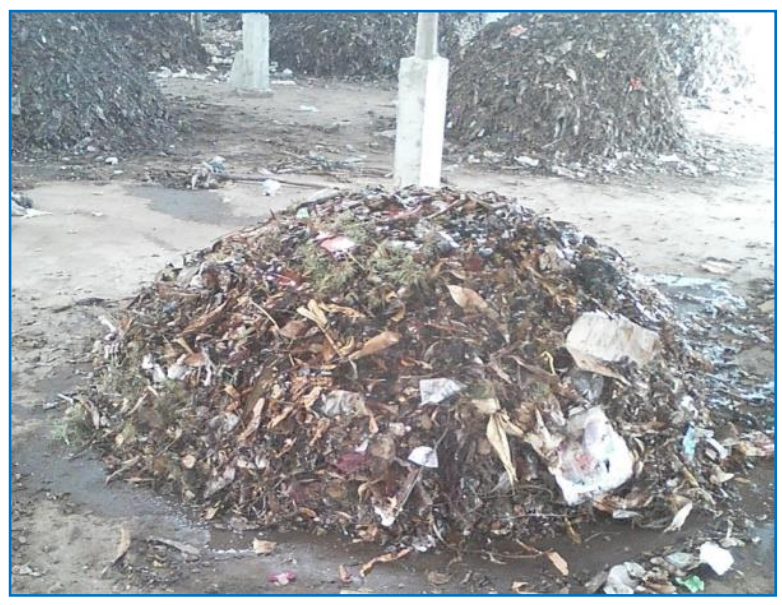

Fig. 2. Triangular shape of windrows with $1.5 \mathrm{~m}$ wide of the base and $1.0-1.5 \mathrm{~m}$ high.

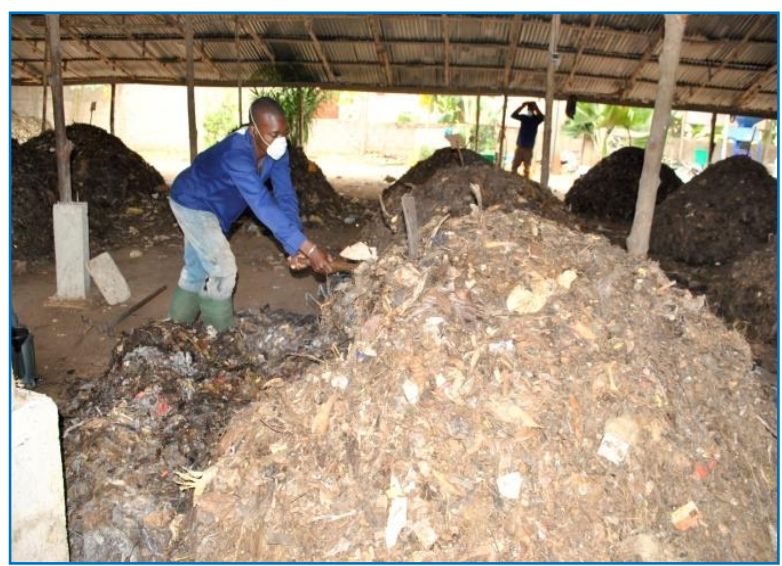

Fig. 3. Aeration of windrow by turning. 


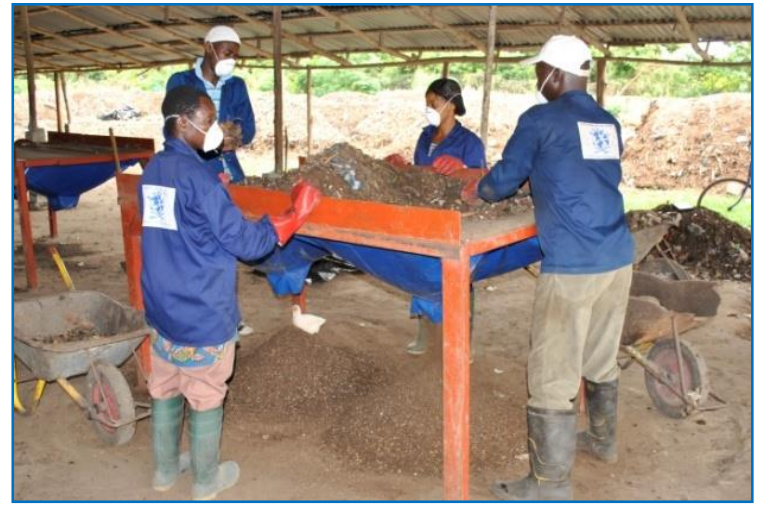

Fig. 4. Matured compost screening.

\section{Composts quality characterization}

Physical characterization of compost: determination of particle size distribution

The distribution of compost particle size was measured. The compost samples were dried at $40^{\circ} \mathrm{C}$ up to one hour and sieved to $>10 \mathrm{~mm}, 5-10$ $\mathrm{mm}, 2-5 \mathrm{~mm}$, and $\leq 2 \mathrm{~mm}$.

\section{Chemical characterization of composts}

Composts obtained were analyzed in laboratory. The $\mathrm{pH}$ was determined at the start until end of composting process. The sample was taken from control and experimental windrows. Each sample was mixed with water in 1:10 to make solution. The prepared solutions were left for 2 hours so that the maximum salts can be dissolved. The $\mathrm{pH}$ electrode was dipped in each sample prepared solution and readings were recorded when it was stabilized (Ameen et al., 2016). The amount of organic carbon content was determined following the wet oxidation method of Walkley and Black (Schnitzer, 1982) while organic matter was obtained using a conversion factor by multiplying the organic carbon content by 1.724 (Sleutel et al., 2007; Luske and Van der Kamp, 2009). The dried material was analyzed to assess nitrogen, phosphorus and potassium contents. The total nitrogen content was determined by distillation of the Kjeldahl method (Bremner and Mulvaney, 1982) after mineralization. The available phosphorus content was analyzed using $0.5 \mathrm{M}$ sodium bicarbonate extraction solution $(\mathrm{pH}=$ 8.5) following the method of Olsen et al. (1954). Exchangeable potassium was extracted using ammonium acetate and thereafter determined by flame photometer (Agbede et al., 2008). The heavy metals: zinc $(\mathrm{Zn})$, copper $(\mathrm{Cu})$, lead $(\mathrm{Pb})$, nickel (Ni) and cadmium (Cd) were determined by Atomic Absorption Spectrophotometer (AAS) after extracting in acid conditions $(\mathrm{HCl} / \mathrm{HNO}=$ 3:1) (Meller et al., 2015; Khan et al., 2016).

\section{Phytotoxicity test of compost}

The phytotoxicity test through germination bioassay test is a simple and reliable indicator of compost maturity. The germination test in this study was conducted on Zea mays and Vigna unguiculata using $100 \%$ sand, $100 \%$ compost and their mixture at mixing ratios of $75 \%$ sand $+25 \%$ compost and $25 \%$ sand $+75 \%$ compost. These crops were selected for their biological standardization in highly sensitive seeds, rapid and easy germination (Koledzi, 2011). Three seeds of each culture were sowed in jugs filled each with $2 \mathrm{~kg}$ of sand, $2 \mathrm{~kg}$ of compost and $2 \mathrm{~kg}$ of each mixture. Four jugs filled with $100 \%$ sand were tested as a control. Germination bioassay was conducted in a complete randomized design with four replications and the mean values were separated on the basis of Duncan Multiple Range Test (DMRT) at a probability level of 0.05. The number of germinated seeds was evaluated during 4 to 7 days after sowing. The phytotoxicity of composts was assessed through germination rate (GR) calculated based on the following equation:

$$
G R(\%)=\frac{A N G S}{N S S} \times 100
$$

Where,

ANGS represents the average number of germinated seeds and NSS is number of seeds sowed.

\section{Data handling}

The results were statistically subjected to Analysis of Variance (ANOVA) using SAS software version 9.2, $2^{\text {nd }}$ edition of 2010. The means separation was performed using the Duncan significance test at $\mathrm{P}<0.05$ level.

\section{Results and Discussion}

\section{Physical characteristics of composts}

Five different composts were obtained. They presented brown color and soil odor (Fig. 5). Their particle size varied between $\leq 2 \mathrm{~mm}$ and $>10 \mathrm{~mm}$ (Table 1 ).

Table 1. Composts particle size distribution (\%).

\begin{tabular}{|lcccccc|}
\hline \multicolumn{1}{|c}{ Fractions } & $\mathrm{CW}_{100}$ & $\mathrm{CW}_{{ }_{4} \mathrm{P}_{15}}$ & $\mathrm{C}_{\mathrm{W}_{70} \mathrm{P}_{30}}$ & $\mathrm{CW}_{\mathrm{F}_{5} \mathrm{M}_{15}}$ & $\mathrm{CW}_{70 \mathrm{M}_{30}}$ & Average \\
\hline$>10 \mathrm{~mm}$ & $10.98 \pm 0.03$ & $\mathbf{1 1 . 0 2} \pm 0.2$ & $8.20 \pm 0.2$ & $8.00 \pm 0.2$ & $7.00 \pm 0.1$ & $9.04 \pm 0.2$ \\
\hline $5-10 \mathrm{~mm}$ & $10.10 \pm 0.02$ & $10.25 \pm 0.3$ & $10.00 \pm 0.4$ & $11.28 \pm 0.5$ & $11.92 \pm 0.3$ & $10.71 \pm 0.2$ \\
\hline $2-5 \mathrm{~mm}$ & $13.40 \pm 0.03$ & $10.62 \pm 0.4$ & $12.60 \pm 0.5$ & $13.71 \pm 0.5$ & $13.09 \pm 0.4$ & $12.68 \pm 0.4$ \\
\hline$\leq 2 \mathrm{~mm}$ & $65.50 \pm 0.06$ & $68.09 \pm 0.6$ & $69.10 \pm 0.7$ & $67.00 \pm 0.5$ & $67.98 \pm 0.4$ & $67.53 \pm 0.6$ \\
\hline
\end{tabular}


The composts obtained have four particle size fractions ( $>10 \mathrm{~mm}, 5-10 \mathrm{~mm}, 2-5 \mathrm{~mm}$ and $\leq 2$ $\mathrm{mm}$ ) (Table 1). It is observed that the particles of size $\leq 2 \mathrm{~mm}$ constitute the important fraction (67.53\%) regardless of the type of composts. The high content of fine particles can be explained by the high levels of fine municipal solid waste and the decomposition process. The similar results was observed by Compaoré et al. (2010) and Charnay (2005) on compost of solid municipal wastes.

Different types of composts enriched some with poultry manure and others with leaves of $M$. pruriens had the highest proportions in fine elements because of the nature of these substrates quickly decomposable into fine elements. In general, all the composts obtained have of better quality because the average refusal part is around 9\% and the proportions of fine particles are higher than 60\% (Compaoré and Nanéma, 2010).

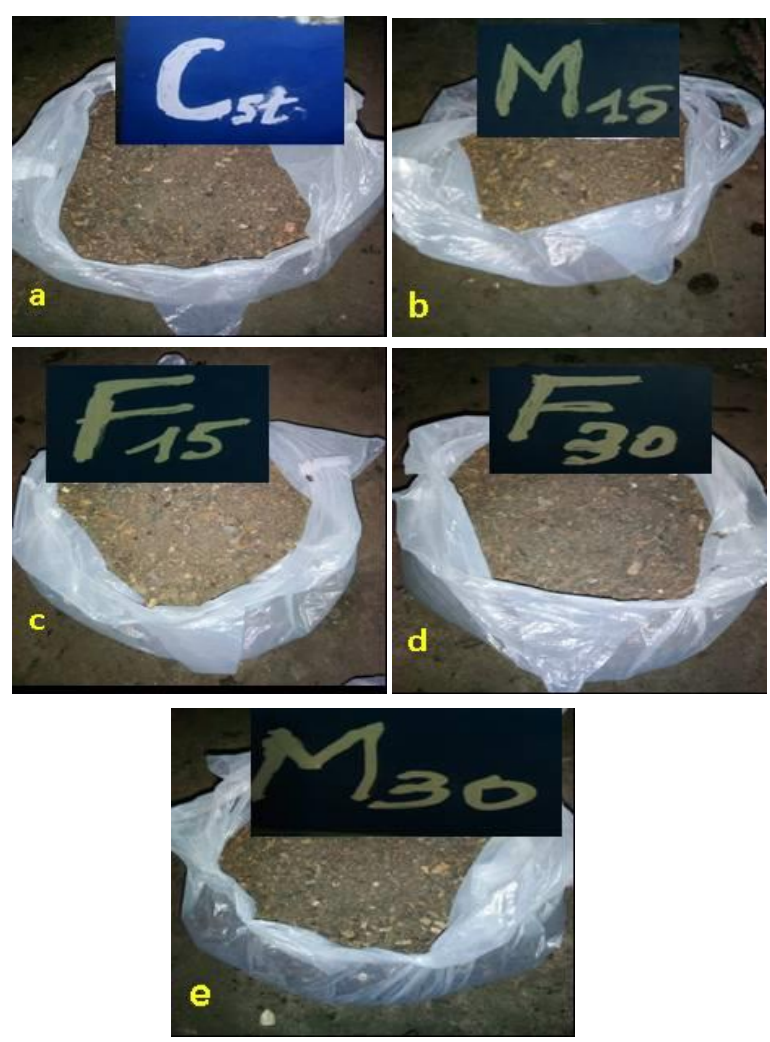

Fig. 5. a. Standard Compost Cwioo (produced by 100\% household waste); b. compost Cw85 $\mathrm{M}_{15}$ (produced by $85 \%$ household waste and $15 \% M$. pruriens leaves); c. compost $\mathrm{Cw}_{5} \mathrm{P}_{15}$ (produced by $85 \%$ household wastes and $15 \%$ poultry manure); d. compost $\mathrm{CW}_{70} \mathrm{P}_{30}$ (produced by $70 \%$ household waste and 30\% poultry manure); e. compost $\mathrm{C}_{\mathrm{W}_{70} \mathrm{M}_{3} \mathrm{O}}$ (produced by $70 \%$ household waste $30 \%$ and $M$. pruriens leaves).

Daily temperature recorded during composting process showed clearly two commonly-seen composting phases: the mesophilic phase with temperature below $45^{\circ} \mathrm{C}$ and the thermophilic phase where temperature increases more than $45^{\circ} \mathrm{C}$. Present results were similar to those reported by (Koledzi et al., 2011; Bazrafshan et al., 2016). A possible reason for this effect may be that: when composting begins, the mesophilic flora (microorganisms able to grow in the $25^{\circ}$ to $45^{\circ} \mathrm{C}$ temperature range) predominate and are responsible for most of the metabolic activity that occurs. This increases the temperature of the composting materials and the mesophilic populations are replaced by thermophilic species, those that thrive at temperatures above $45^{\circ} \mathrm{C}$. This rise in temperature is influenced to a great extent by oxygen availability. Windrows kept for the most part aerobic reach temperatures up to $70^{\circ} \mathrm{C}$ and produce few objectionable odors. The data related to the effect of temperature on the composting process indicate that optimum decomposition takes place between 55 and $70^{\circ} \mathrm{C}$.

The presence of more easily biodegradable compounds in windrows of $M$. pruriens leaves and poultry manure could explain the difference showed in the thermophilic phase during. In fact, organic matter degradation was greater in windrows in the mixture with $M$. pruriens leaves and poultry manure which may be explained by the longer thermophilic phase for these windrows. The temperature was maintained between 60 and $70^{\circ} \mathrm{C}$ for about 60 days, which will contribute to the transformation of highly polymerized substrate (lignin and cellulose) by thermophilic microorganisms and to the hygienization of the end product (compost) due to pathogen, weed and seed reduction. When the temperature started to decrease, the windrows were turned in order to improve the homogeneity of the fermentation process. The thermophilic phase lasted approximately 80 days for mixtures waste $+M$. pruriens leaves and waste + poultry manure, respectively. The bio-oxidative phase of composting was considered finished when the temperature of the windrows was stable and close to that of the atmosphere. This occurred after 120 and 130 days in waste $+M$. pruriens leaves and waste + poultry manure, respectively.

\section{Chemical characteristics of composts}

Composts analyzed shown nitrogen content varying from 1.02 to $2.72 \%$, phosphorus content varying from 1.35 to $2.70 \%$, potassium content varying from 1.31 to $1.72 \%$, organic carbon content varying from 13.40 to $21.95 \%$ and organic matter content varying from 23.5 to $37.75 \%$ (Table 2). The nutrient contents of studied composts were comparable to those determined by Compaoré et al. (2010) and can be used as fertilizer. Composts maturity is often assessed by the $\mathrm{C} / \mathrm{N}$ ratio. It has been established that a $\mathrm{C} / \mathrm{N}$ ratio between 10 and 15 corresponds to mature compost (Namkoong et al., 1999). The averages $\mathrm{C} / \mathrm{N}$ ratios determined in this study were comprised between 8.06 and 13.13 indicating that the composts would be mature (Table 2). 
Maturity is a term used to specify the level of phytotoxic substance in compost samples and compost appropriateness for plant growth
(Brewer and Sullivan, 2003; Aslam et al., 2008). The $\mathrm{pH}$ in final products were between 8.50 and 9.00 (Table 2).

Table 2. Compost chemical characteristics.

\begin{tabular}{|c|c|c|c|c|c|c|c|}
\hline $\begin{array}{l}\text { Types of } \\
\text { composts }\end{array}$ & $\mathrm{pH}-\mathrm{H}_{2} \mathrm{O}$ & $\% \mathrm{OM}$ & \% C. Org. & $\% \mathrm{~N}$ tot. & $\mathrm{C} / \mathrm{N}$ & $\% \mathrm{P}_{2} \mathrm{O}_{5}$ & $\% \mathrm{~K}_{2} \mathrm{O}$ \\
\hline CW1oo & $8.50 \pm 0.2 b$ & $23.50 \pm 0.4$ & $13.40 \pm 0.5 \mathrm{c}$ & $1.02 \pm 0.1 \mathrm{c}$ & $13.13 \pm 0.2 \mathrm{a}$ & $1.35 \pm 0.3 b$ & $1.40 \pm 0.6 \mathrm{a}$ \\
\hline $\mathrm{Cw}_{85} \mathrm{P}_{15}$ & $8.84 \pm 0.2 \mathrm{ab}$ & $30.10 \pm 0.3$ & $17.50 \pm 0.3 \mathrm{~b}$ & $1.90 \pm 0.2 b$ & $9.21 \pm 0.3 \mathrm{~b}$ & $2.31 \pm 0.1 \mathrm{a}$ & $1.31 \pm 0.2 \mathrm{a}$ \\
\hline $\mathrm{CW}_{70} \mathrm{P}_{30}$ & $8.98 \pm 0.3 a$ & $34.19 \pm 0.3$ & $19.88 \pm 0.3 b$ & $2.51 \pm 0.3 a$ & $8.28 \pm 0.3 \mathrm{c}$ & $2.60 \pm 0.3 a$ & $1.72 \pm 0.3 a$ \\
\hline $\mathrm{C}_{\mathrm{W} 85 \mathrm{M} 15}$ & $8.90 \pm 0.2 a b$ & $34.17 \pm 0.4$ & $19.87 \pm 0.2 b$ & $2.00 \pm 0.3 b$ & $9.93 \pm 0.2 b$ & $2.50 \pm 0.2 \mathrm{a}$ & $1.60 \pm 0.3 a$ \\
\hline $\mathrm{C}_{\mathrm{W}_{70} \mathrm{M}_{30}}$ & $9.00 \pm 0.3 a$ & $37.75 \pm 0.5$ & $21.95 \pm 0.3 \mathrm{a}$ & $2.72 \pm 0.2 \mathrm{a}$ & $8.06 \pm 0.2 \mathrm{c}$ & $2.70 \pm 0.4 a$ & $1.65 \pm 0.2 \mathrm{a}$ \\
\hline CV (\%) & 3.00 & - & 2.10 & 15.20 & 3.70 & 8.40 & 22.90 \\
\hline $\mathrm{PPDS}_{5 \%}$ & 0.43 & - & 0.62 & 0.53 & 0.59 & 0.43 & 0.64 \\
\hline
\end{tabular}

The values of the same column assigned to the same index of letters are statistically identical to the threshold of $5 \%$.

\section{Organic matter evolution}

The organic matter content in windrows decreased during the composting process, showing the removal of organic matter through microbial activity. The loss of organic matter in the finished product is a result of the biodegradation by microorganisms during the fermentation process. At the beginning of composting, the $\mathrm{C} / \mathrm{N}$ ratio increased. This increase would be the consequence of the leaching of nitrogen through the liquid phase. Organic matter degradation was more important in the mixtures: waste $(70 \%)+$ poultry manure $(30 \%)$ and waste $(70 \%)+M$. pruriens leaves (30\%), which may be due to the longer thermophilic phase for these windrows. According to Paredes et al. (2000), this fact can be explained by the higher content of easily degradable organic compounds provided by poultry manure and M. pruriens leaves.

The difference between composts can be attributed to the higher content of easily degradable organic compounds provided by poultry manure and $M$. pruriens leaves. Organic matter decomposition bring about an increase in $\mathrm{pH}$, as recorded by Paredes et al. (2000), which was explained as a consequence of the degradation of acid-type compounds, such as carboxylic and phenolic groups, the mineralization of compounds, such as proteins, amino acids and peptides, to ammonia and the relative increased concentration of ions, due to the loss of windrows weight. This fact was observed in the higher $\mathrm{pH}$ of composts.

Evolution of $\mathrm{pH}$ values during the composting process

At the beginning of the composting process, the samples of composts showed (Fig. 6) an acidic $\mathrm{pH}$ as a result of organic acids being released from biodegradation of polycarbohydrates (Iglesias and Perez, 1991). During the composting process all samples showed (Fig. 6) continuous increase of $\mathrm{pH}$ values as a result of biodegradation of organic acids (Iglesias and Perez, 1991) and biodegradation of organic matter containing nitrogen (proteins, amino acids etc.) leading to formation of amines and ammonia salts through mineralization of organic nitrogen (Dumitrescu et al., 2009). Changes in the $\mathrm{pH}$ through time are a function of the fluctuating alkalinity during the composting process (Komilis and Ham, 2006). All composts recorded a $\mathrm{pH}$ above 8.5 which can induce the volatilization loss of ammonia as the acid/base equilibrium shifts from $\mathrm{NH}_{4}^{+}$to $\mathrm{NH}_{3}$ $(\mathrm{pKa}=9.2)$ (Fadiran and Dube, 2009). $\mathrm{A} \mathrm{pH}$ of 6.3 - 9.0 supports good microbial activity during composting. Usually $\mathrm{pH}$ is a factor which is very relevant for controlling $\mathrm{N}$-losses by ammonia volatilization, which can be particularly high at $\mathrm{pH}>7.5$ (De Bertoldi et al., 1983). The results of control and experimental windrows in term of $\mathrm{pH}$ value were almost same. All windrows showed alkaline $\mathrm{pH}$ throughout the composting process, in the range of 8.5 to 9.0. The alkaline $\mathrm{pH}$ is important parameter to evaluate compost maturity and stability. The acidic $\mathrm{pH}$ affects the rate of respiration of microbes and decreases the rate of degradation. The $\mathrm{pH}$ of the compost should be alkaline throughout and end of the composting process. The high activity of microbes at thermophilic stage is because of the alkaline pH (Sundberg et al., 2004).

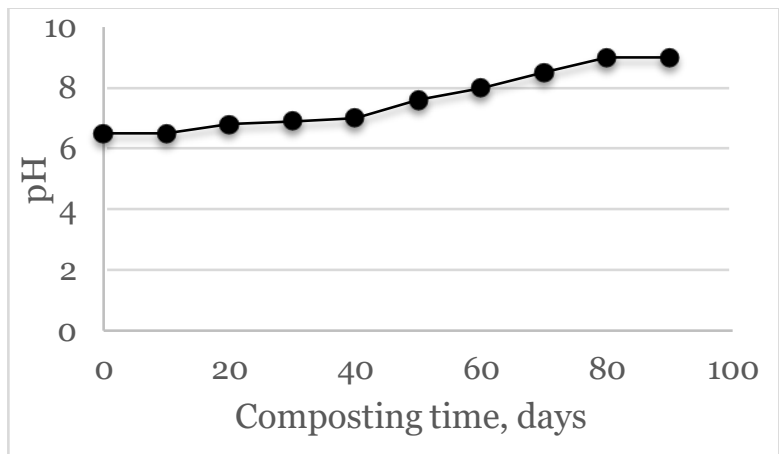

Fig. 6. $\mathrm{pH}$ evolution during the composting process. 


\section{Heavy metal content in final product}

The concentrations of the selected heavy metals: zinc $(\mathrm{Zn})$, copper $(\mathrm{Cu})$, lead $(\mathrm{Pb})$, nickel $(\mathrm{Ni})$ and cadmium (Cd) in the compost samples are presented in Table 3. As shown in Table 3, the heavy metal contents in the final products were lower than the regulation limits prescribed by the US EPA (Bazrafshan et al., 2016) for exceptional quality compost and did not exceed admissible values listed in the French Regulation (AFNOR,
2005) for organic and organic-mineral fertilizers. The zinc and copper concentrations were relatively higher than other heavy metals. Comparing the obtained results for heavy metal concentrations with those, our results were in agreement with the findings of other researchers. Many authors' papers confirm a substantial content of heavy metal in composts produced from municipal solid waste (Koledzi et al., 2014; Meller et al., 2015).

Table 3. Means concentrations of heavy metals in composts and standard deviations $(n=5)$ $(\mathrm{mg} / \mathrm{kg} \cdot \mathrm{dm})$.

\begin{tabular}{|ccc|ccccc|}
\hline $\begin{array}{c}\text { Heavy } \\
\text { metal }\end{array}$ & $\mathrm{C}_{\mathrm{W}_{100}}$ & $\mathrm{C}_{\mathrm{W}_{5} \mathrm{P}_{15}}$ & $\mathrm{C}_{\mathrm{W}_{70} \mathrm{P}_{30}}$ & $\mathrm{C}_{\mathrm{W}_{5} \mathrm{M}_{15}}$ & $\mathrm{C}_{\mathrm{W}_{70} \mathrm{M}_{30}}$ & $\begin{array}{c}\text { Limited } \\
\text { values}\end{array}$ & $\begin{array}{c}\text { Regulation } \\
\text { limits }\end{array}$ \\
\hline $\mathrm{Zn}$ & $140.2 \mathrm{O} \pm 1.60$ & $96.90 \pm 1.90$ & $89.70 \pm 1.60$ & $94.60 \pm 1.80$ & $79.80 \pm 1.70$ & 600 & 2800 \\
\hline $\mathrm{Cu}$ & $76.60 \pm 1.03$ & $67.40 \pm 1.10$ & $39.20 \pm 1.02$ & $59.80 \pm 1.03$ & $27.10 \pm 1.01$ & 300 & 1500 \\
\hline $\mathrm{Pb}$ & $9.19 \pm 0.22$ & $4.52 \pm 0.12$ & $3.09 \pm 0.32$ & $7.05 \pm 0.26$ & $2.07 \pm 0.33$ & 180 & 300 \\
\hline $\mathrm{Ni}$ & $11.05 \pm 0.36$ & $6.70 \pm 0.22$ & $4.13 \pm 0.16$ & $9.34 \pm 0.32$ & $5.63 \pm 0.06$ & 60 & 420 \\
\hline $\mathrm{Cd}$ & $2.15 \pm 0.03$ & $1.10 \pm 0.01$ & $0.79 \pm 0.02$ & $1.09 \pm 0.01$ & $0.93 \pm 0.01$ & 3 & 39 \\
\hline
\end{tabular}

* Limited value for heavy metals prescribed by French regulation (AFNOR, 2005)

** Regulation limits for heavy metals prescribed by the US EPA (Bazrafshan et al., 2016)

\section{Germination rate of maize and cowpea seeds on different composts}

The five types of composts elaborated were subjected to the germination test on two crops: cowpea and maize. Table 4 shows the results of the germination test. These results show that the mixture of $25 \%$ of compost and $75 \%$ of sand provides best germination rates of $100 \%$ for maize and $93.4 \%$ for cowpea. From the mixture of $75 \%$ compost and $25 \%$ sand, resulted the germination rates of $100 \%$ for maize and $86.80 \%$ for cowpea. The germination rates of maize and cowpea seed with pure compost are respectively $59.8 \%$ and $51.2 \%$ compared to $100 \%$ for pure sand (Table 4). These germination rates comprised between $51.2 \%$ and $100 \%$ allowed to conclude that the composts studied are mature and have no phytotoxicity (Zucconi et al., 1981; Toundou, 2016). In general, it is observed that germination rates of maize are slightly higher than those of cowpea (Table 4). It can be deduced that the germination rate is a function of the crop. Similar findings were made by Compaoré et al. (2010) with a germination test on maize and groundnuts.

According to these authors, the cereal seems to be more sensitive to high compost doses compared to the vegetables and would not be better recommendable for evaluating the phytotoxicity of composts. Compost enriched with poultry manure has germination rates ranging from 57 to $100 \%$ for maize and 45.5 to $100 \%$ for cowpea.

Table 4. Average germination rate (\%) of maize (Zea mays) and cowpea seed (Vigna unguiculata) on sand, compost and mixture sand + compost.

\begin{tabular}{|c|c|c|c|c|c|}
\hline $\begin{array}{l}\text { Type of } \\
\text { compost }\end{array}$ & Crop seed & $100 \%$ Sand & $\begin{array}{l}75 \% \text { Sand }+ \\
25 \% \text { compost }\end{array}$ & $\begin{array}{l}25 \% \text { Sand }+ \\
75 \% \text { compost }\end{array}$ & $100 \%$ compost \\
\hline \multirow{2}{*}{$\mathrm{C}_{W 100}$} & Cowpea & 100 & 100.00 & 100.00 & 54.00 \\
\hline & Maize & 100 & 100.00 & 100.00 & 57.00 \\
\hline \multirow[t]{2}{*}{$\mathrm{CW}_{85} \mathrm{P}_{15}$} & Cowpea & 100 & 100.00 & 67.00 & 34.00 \\
\hline & Maize & 100 & 100.00 & 100.00 & 57.00 \\
\hline \multirow[t]{2}{*}{$\mathrm{CW}_{70} \mathrm{P}_{30}$} & Cowpea & 100 & 67.00 & 100.00 & 57.00 \\
\hline & Maize & 100 & 100.00 & 67.00 & 57.00 \\
\hline \multirow{2}{*}{$\begin{array}{l}\text { Average } \\
\text { Poultry }\end{array}$} & Cowpea & 100 & 83.50 & 83.50 & $45 \cdot 50$ \\
\hline & Maize & 100 & 100.00 & 83.50 & 57.00 \\
\hline \multirow{2}{*}{$\mathrm{C}_{\mathrm{W} 85 \mathrm{M} 15}$} & Cowpea & 100 & 100.00 & 100.00 & 54.00 \\
\hline & Maize & 100 & 100.00 & 100.00 & 74.00 \\
\hline \multirow[t]{2}{*}{$\mathrm{CW}_{\mathrm{W}_{70} \mathrm{M}_{30}}$} & Cowpea & 100 & 100.00 & 67.00 & 57.00 \\
\hline & Maize & 100 & 100.00 & 100.00 & 54.00 \\
\hline \multirow{2}{*}{$\begin{array}{l}\text { Average } \\
\text { Mucuna }\end{array}$} & Cowpea & 100 & 100.00 & 83.50 & $55 \cdot 50$ \\
\hline & Maize & 100 & 100.00 & 100.00 & 64.00 \\
\hline \multirow[t]{2}{*}{ Average rate } & Cowpea & 100 & 93.4 .00 & 86.80 & 51.20 \\
\hline & Maize & 100 & 100.00 & 93.40 & 59.8 .00 \\
\hline
\end{tabular}


On the other hand, compost enriched with leaves of $M$. pruriens has germination rates ranging from 64.00 to $100.00 \%$ for maize and 55.50 to $100.00 \%$ for cowpea (Table 4). Considering the nature of the substrates incorporated in composts, it is noted that the germination rates observed with composts containing poultry manure are slightly lower than those of composts containing the leaves of $M$. pruriens. This difference can be explained by the fact that the poultry manure contains ammoniac which would reduce the seed germination rate as already reported by Jimenez and Garcia (1989) and Tang et al. (2006).

\section{Agronomic quality of the composts}

The laboratory analysis to determine the agronomic quality of the final products showed mature composts with $\mathrm{C} / \mathrm{N}$ ratio comprises between 8 and 13, and $\mathrm{pH}$ between 8.5 and 9.0 (Table 2). The $\mathrm{pH}$ and Electrical conductivity values for the samples of composts at the end of composting process are optimal for agricultural purposes. This is comparable to $\mathrm{pH}$ and electrical conductivity mean values in municipal solid waste compost reported in the literature (Mathur et al., 1993; Kaseva et al., 2002; Barje et al., 2016). The ideal $\mathrm{C} / \mathrm{N}$ ratio of mature compost is about 10, which approaches that of humus. This is the case of our products (composts). However, this value is almost never achieved because of differences in bioavailability of compost mixtures (Mathur et al., 1993). This study shows that all organic fraction waste was favorable to produce a good fertilizer with no phytotoxicity, this refers to the basic elements (nitrogen, potassium, phosphorus, and organic matter) and to the rates of germination test, which should not vary in the finished product if the leaching is avoided.

\section{Conclusion}

This study has shown that, by using composting technology, it is possible to transform household urban solid wastes generated in district of Agbalepedogan in Lome mixed with poultry manure and Mucuna pruriens leaves in appropriate percentages into composts (organic fertilizers) with no phytotoxicity useful to improve soil fertility. It can be deduced that composting is a suitable alternative for the recycling urban solid wastes into organic fertilizers. This technology constitutes household wastes management to obtain added-value composts with future potential uses in agriculture.

\section{Acknowledgements}

The authors would like to thank Laboratory for Management, Treatment and Value of Waste, University of Lomé (GTVD/UL) and No Organization Governmental ENPRO (Clean Natural Ecosystem), for their kind support and cooperation in conducting the study.

\section{References}

AFNOR. 2005. Organic amendments denominations, specifications and marking. Eds AFNOR. 16p.

Agbede, T.M., Ojeniyi, S.O. and Adeyemo, A.J. 2008. Effects of poultry manure on soil physical and chemical properties, growth and grain yield of sorghum in Southwest, Nigeria. American Eurasian J. Sust. Agric. 1(2): $72-77$.

Ameen, A., Ahmad, J. and Raza, S. 2016. Effect of $\mathrm{pH}$ and moisture content on composting of Municipal solid waste. Int. J. Sci. Res. Pub. 6(5): $35-37$.

Aslam, D., Horwath, W. and VanderGheynst, J.S. 2008. Comparison of several maturity indicators for estimating phytotoxicity in compost-amended soil. Waste Manage. 28: $2070-2076$.

Barje, F., Meddich, A., Hajjouji, H., El Asli, A., Baddi, G., El Faiz, A. and Hafidi, M. 2016. Growth of date palm (Phoenix dactylifera) in composts of olive oil mill waste with organic household refuse. Compost Sci. Utili. 24(4): $273-280$.

Bazrafshan, E., Zarei, A., Mostafapour, F.K., Poormollae, N., Mahmoodi, S. and Mohammad Ali Zazouli, M.A. 2016. Maturity and stability evaluation of composted municipal solid wastes. Health Scope. 5(1): 1 - 9 .

Bremner, J.M. and Mulvaney, C.S. 1982. Total nitrogen In: C.A. Black. (Ed.) Methods of Soil Analysis. Part 2, Agronomy 9. American Society of Agronomy Inc. Madison, Wisconsin. pp. $1149-1178$.

Brewer, L.J. and Sullivan, D.M. 2003. Maturity and stability evaluation of composted yard trimmings. Compost Sci. Utili. 11: 96 - 112.

Caravaca, F., Figuerou, D., Alguacil, M.M. and Roldan, A. 2003. Application of composted urban residue enhanced the performance of afforested shrub species in a degraded semiarid land. Bioresource Tech. 90: 65 - 70.

Charnay, F. 2005. Compostage des déchets urbains dans les Pays en Développement: élaboration d'une démarche méthodologique pour une production pérenne de compost. Thèse de Doctorat, Discipline: Chimie et microbiologie de l'eau, Ecole Doctorale Science-Technique-Santé, Université de Limoges. 229p.

Compaoré, E. and Nanéma, L.S. 2010. Compostage et qualité du compost de déchets urbains solides de la ville de BoboDioulasso, Burkina Faso. Tropicultura. 4: $232-237$.

Compaoré, E., Nanema, L.S., Bonkoungou, S. and Sedogo, M.P. 2010. Evaluation de la qualité de composts de déchets urbains solides. $J$. Appl. Biosci. 33: 2076 - 2083.

De Bertoldi, M., Vallini, G. and Pera, A. 1983. The biology of composting. Waste Manage. Res. 1: $157-176$. 
Dumitrescu, L., Manciulea, I., Sauciuc, A. and Zaha, C. 2009. Obtaining fertilizer compost by composting vegetable waste, sewage sludge and sawdust. Bull. Transilvania Univ. Brasov. 2 (51): 117- 122.

Fadiran, A.O. and Dube, S.P. 2009. A study of the relative levels and factors in the analysis of total ammonia nitrogen in some surface and groundwater bodies of Swaziland. Asian $J$. Appl. Sci. 2: $363-371$.

Gamal, A.R. 2009. Impacts of compost on soil properties and crop productivity in the Sahel North Burkina Faso. American- Eurasian $J$. Agril. Env. Sci. 6(2): 220 -226.

Iglesias, J.E. and Perez, G.V. 1991. Composting of domestic refuse and sewage sludge: Evolution of temperature, $\mathrm{pH}, \mathrm{C} / \mathrm{N}$ ratio and cation-exchange capacity. Resources Conserv. Recycl. 6: 45-60.

Jimenez, E.I. and Garcia, V.P. 1989. Evaluation of city refuses compost maturity: a review. Biol. Wastes. 27: $115-142$.

Kaseva, M.E., Mbuligwe, S.E. and Kasbenga, G. 2002. Recycling inorganic solid waste: results from a pilot study in Dares Salaam. Resource Conserv. Recycl. 35: 243 - 257.

Khan, T.F., Ullah, M.W. and Huq, S.M.I. 2016. Heavy metal contents of different wastes used for compost. J. Minerals Materials Character. Eng. 4: 241 - 249.

Koledzi, E.K., Baba, G., Tchangbedji, G., Agbeko, K., Matejka, G., Feuillade, G. and Bowen, J. 2011. Experimental study of urban waste composting and evaluation of its agricultural valorisation in Lomé (Togo). Asian J. Appl. Sci. 4(4): $378-391$.

Koledzi, E.K., Baba, G., Tchegueni, S., Segbeaya, K.N., Koriko, M., Matejka, G. and Tchangbedji, G. 2014. Composting of urban solid waste in Lomé, Togo: fate of some heavy metals ( $\mathrm{Ni}, \mathrm{Cu}, \mathrm{Zn}, \mathrm{Pb}$ and $\mathrm{Cd})$. Int. J. Biol. Chem. Sci. 8(2): 821 - 830.

Koledzi, K.E. 2011. Valorisation des déchets solides urbains dans les quartiers de Lomé (Togo): approche méthodologique pour une production durable de compost. Thèse de Doctorat, Faculté des Sciences et Techniques, Université de Lomé. 224p.

Komilis, D.P. and Ham, R.K. 2006. Carbon dixiode and ammonia emissions during composting of mixed papers, yard waste and food waste. Waste Manage. 26: 62 - 70.

Luske, B. and Van der Kamp, J. 2009. Carbon sequestration potential of reclaimed desert soils in Egypt. Louis Bolk Instituut Soil \& More Int. 35p.

Mathur, S.P., Owen, G., Dinel, H. and Schnitzer, M. 1993. Determination of compost biomaturity. Literature review. Biol. Agric. Hort. 10: $65-85$.
Meller, E., Niedzwiecki, E., Rogalska, P., Jarnuszewski, G. and Wilczynski, D. 2015. Fertilizer value and trace element content of composts produced from different wastes. $J$. Ecol. Eng. 16(4): $154-160$.

Namkoong, W., Hwang, E.Y., Cheong, J.G. and Choi, J.Y. 1999. A comparative evaluation of maturity parameters for food waste composting. Compost Sci. Utili. 7: 55 - 62.

Olsen, S.R., Cole, C.V., Watanabe, F.S. and Dean, L.A. 1954. Estimation of available phosphorus in soils by extraction with sodium bicarbonate. USDA Circular. 939: 119.

Ouédraogo, E., Mando, A. and Zombré, N.P. 2001. Use of compost to improve soil properties and crop productivity under low input agricultural system in West Africa. Agric. Ecosyst. Environ. 84: 259 - 266.

Paredes, C., Roig, A., Bernal, M.P., SanchezMonedero, M.A. and Cegarra, J. 2000. Evolution of organic matter and nitrogen during co-composting of olive mill wastewater with solid organic wastes. Biol. Fert. Soils. 32: 222-227.

Schnitzer, M. 1982. Total carbon, organic matter, and carbon. In: Methods of Soil Analysis Part II. Page, A.L. (Ed.). Chemical and Microbiological Properties. American Society of Agronomy, Madison. Part 2, Agronomy Monograph, 9, 2nd ed., WI. pp. $539-577$.

Sleutel, S., De Neve, S., Singier, B. and Hofman, G. 2007. Quantification of Organic Carbon in Soils: A Comparison of Methodologies and Assessment of the Carbon Content of Organic Matter. Comm. Soil Sci. Plant Analysis. 38: 2647 - 2657.

Sundberg, C., Smårs, S. and Jönsson, H. 2004. Low $\mathrm{pH}$ as an inhibiting factor in the transition from mesophilic to thermophilic phase in composting. Bioresource Tech. 95(2): 145-150.

Tang, J.C., Maie, N., Tada, Y. and Katayama, A. 2006. Characterization of the maturing process of cattle manure compost. Process Biochem. 41: 380 - 389.

Toundou, O. 2016. Evaluation des caractéristiques chimiques et agronomiques de cinq composts de déchets et étude de leurs effets sur les propriétés chimiques du sol, la physiologie et le rendement du maïs (Zea mays L. Var. Ikenne) et de la tomate (Lycopersicum esculentum L. Var. Tropimech) sous deux régimes hydriques au Togo. Thèse de Doctorat, Faculté des Sciences et Techniques, Université de Lomé (Togo). 213p.

Zucconi, F., Pera, A., Forte, M. and De Bertoldi, M. 1981. Evaluating toxicity of immature compost. Biocycle. 22: 54 - 57 . 